\title{
Resisting Invisibility through Creative Expressions: Immigrant Students and Families' Voices and Actions
}

\author{
Leticia Alvarez Gutiérrez \\ University of Utah \\ USA
}

\author{
Patricia D. Quijada Cerecer \\ University of California, Davis \\ USA
}

\begin{abstract}
This study examines a grassroots effort to work collaboratively with a group of immigrant students, their families, and educators at an urban high school. Using Critical Participatory Action Research (CPAR) as a methodological tool, we explore how a group of high school students, along with their families, resist racial stigmatization and marginalization. CPAR is an approach that emphasizes the active participation of co-researchers in identifying the issues to be researched as well as participate in the planning, implementation, and distribution of research through action. These young people and families were part of a university intergenerational collective, Family School Partnership (FSP), that worked alongside teachers in an urban high school located in Salt Lake City, Utah. This article focuses on how CPAR can be a pedagogical tool to support immigrant young people and their families as they resist oppressions in schools, while offering teachers, pre-service teachers, and graduate students unique preparation experiences for working with and learning from immigrant students.
\end{abstract}

Keywords: culturally sustaining pedagogy, family school engagement, immigrant students, critical participatory action research, refugee students, teacher education 
I speak Somali and a little bit of Swahili...for me, leaving my home country was the saddest thing. It is hard to leave a place that you know about and the place where you were born. It is just as hard and .... the other thing is when my mom passed away... -Maryan

We cannot fly back to Hong Kong every summer. The tickets are too expensive, and my dad cannot afford that much. So, my dad calls us every morning and night. That is the only way we can talk to each other. I miss my dad so much. I really want my family to be together every day. I really want to see my dad, so I found my first job. I work at Smiths. I do everything to save so I can see my dad. I wish someday he will come to live with us. -Jonathan

My dad got deported to México. He did not have a choice. They deported him without money or his valuables. -Ricardo

We got a call from México saying that my dad was dead. My mom hugged us and said: "Todo va estar bien, los tres vamos a vivir felices." [Everything will be okay. The three of us will live happy]. -Susana

Above, Maryan, Jonathan, Ricardo, and Susana detail challenging moments and the emotional pain they experienced immigrating to the United States. These high school students, along with several family members, formed part of a participation action research collective that held space for each other and lifted some to share their immigration journeys. The dynamics that led to them sharing their at times intensely personal and painful experiences in the US is not a simple one nor one that can be replicated since the building of human relationships is not a mechanical process. Yet, the young people, families, and educators came together and collectively explored racial issues and inequities that were part of the institutional fabric at Hope ${ }^{1} 1$ high school.

Their ongoing engagement and active participation in the Critical Participatory Action (CPAR) research project positioned the young people as essential members of our research team. The team emerged from a Family-School-University partnership and included students pursuing high school diplomas, secondary teaching credentials, and graduate degrees as well as teachers and family members. Collectively the team imagined and created a Critical Participatory Action Research classroom-based project that honored immigrant and refugee students' immigration experiences and positioned them as active learners engaged in the production of knowledge. During our weekly gatherings, young people and their families revealed the pain and distress experienced throughout their journey to and into the United States. Leaving their homeland, being separated from family, and experiencing the loss of a parent or loved one are only some of the experiences immigrant and refugee students bring to public schools. The impact of these experiences are complex and layered for immigrant students, particularly undocumented students who are navigating xenophobic environments in the United States (Alvarez Gutiérrez, 2015; Alvarez Gutiérrez \& Quijada Cerecer, 2016; Alvarez \& Rios, 2012). This article focuses on how CPAR became a critical pedagogical tool to understand, support and legitimize students' turbulent experiences immigrating to the United States and in schools. As such, the CPAR project titled Creative Expressions offered students an opportunity to express, reflect, and acknowledge the pain and love they experienced as they move through school hallways, classrooms, and the US.

While for some this was not a new process, for others, sharing intimate painful moments opened the doorway to feel and recognize themselves as holistic beings. Students also had the opportunity to learn about research and the complex ways it can be a tool to enact political change. 
Equally important, teachers, pre-service teachers, and graduate students were also afforded unique opportunities to work with and learn from immigrant and refugee students and their families. The CPAR project provided an opportunity for young people to pause, reflect, and disentangle the deficit narratives that positioned them as young immigrants and as learners. That is, the CPAR project served as a pedagogical tool whereby young people were able to actively engage in the learning process as active change agents and knowledge producers. This project became significant for students and families, given the relationship between the persistent anti-immigrant discourse in the US and the institutional violence targeting immigrant students and communities

Anti-immigrant rhetoric in the US has been relentless and continues to be sustained by a continual flow of xenophobic legislation and policies. In combination, these policies reinforce immigrants' liminal legality, regardless of their documentation status (Menjivar, 2006). Recent examples of such legislation and policies include travel bans to the United States for nationals of Libya, Yemen, Somalia, and Venezuela traveling with business and immigrant visas, and nationals from North Korea and Syria are completely banned from traveling into the United States (see Executive Order 13780). The current administration has also sought to eradicate the executive order, Deferred Action for Childhood Arrivals (DACA), authorized in 2012 by President Obama. Fortunately, these efforts have been contested and DACA has been sustained, albeit in different forms and remains temporal. Most recently, the Trump administration enacted a policy that separates immigrant children from their families when seeking asylum at the US-México border. As a result, many families, including children, young people, and adults have symptoms of anxiety and depression and can find it difficult to trust adults and educational institutions, including educators in schools. In combination, these policies promote deficit notions of students' academic identities rather than engage with immigrant students' knowledge, imaginations, and visions for the future. Because these policies diminish students' engagement in learning (American Psychological Association, nd), and the anti-immigrant rhetoric and legislation influence educational policies, school leadership, and pedagogical practices, they reveal how systems of power interact, intersect, and impact students of color and immigrant students in K12 school systems (Alvarez Gutiérrez, 2015; Alvarez Gutiérrez \& Quijada Cerecer, 2016; Cahill, Alvarez Gutiérrez, \& Quijada Cerecer, 2016; Camarota, Griffith, \& Zeigler, 2017; Paris \& Alim, 2017; Passos DeNicolo, Yu, Crowley, \& Gabel, 2017).

\section{US Demographics \& Educational Disparities}

Currently, people of color make up $37 \%$ of the overall US population, and projections suggest an increase to $57 \%$ by 2060 , of which Latinx will constitute $31 \%$ (US Census Bureau, 2015). There are also approximately 43.7 million immigrants residing in the US, accounting for 13.5 percent of the total US population (US Census Bureau, 2015). In the US public school system, the number of students of color enrolling in preK-12 reveals a similar trend. In the fall of 2018, slightly more than half of all preK-12 students enrolled in public schools will be students of color (NCES, 2018). Reports suggest that white students will comprise 24.1 million of the 50.7 million students enrolled, and 26.6 million will include 7.8 million Black students, 14.0 million Latinx students, 2.6 million Asian students, 0.2 million Pacific Islander students, 0.5 million American Indian/Alaska Native students, and 1.6 million bi- and multiracial students (US Department of Education, 2018). While the enrollment of minoritized and multiracial students in public schools will continue to increase through fall 2027 (NCES, 2018), of serious concern is the low number of educators of color. Currently, only 20 percent of all educators in the United States are of ethnic and racially diverse backgrounds (Geiger, 2018), which means that students have very few teachers who share their backgrounds. 
While the demographics of students in public education continue to shift, schools and other educational organizations remain mired in systems that are infused with structural racism (Alvarez Gutiérrez \& Quijada Cerecer, 2016; Bonilla Silva, 2015; Gregory, Skiba, \& Noguera, 2010). Structural racism accounts for the multitude of ways knowledge production is racialized in K-12 schools. Texts and curricula often exclude, devalue, or alter contributions made by culturally and linguistically diverse students, families, and their communities (Alvarez Gutiérrez, 2015; Alvarez Gutiérrez \& Quijada Cerecer, 2016). In schools, immigrant students' epistemologies are often evaluated using metrics that position young people in deficit ways and result in inequitable access, opportunities, power, treatment, and policies that push students out of school (Alvarez Gutiérrez, 2015). Purportedly race-neutral policies further support and sustain the racialization and validity of knowledge (Gregory, Skiba, \& Noguera, 2010). For example, English-only policies in schools are considered to be seemingly race neutral; however, ethnically and linguistically diverse students are diciplined and/or suffer consequences for speaking their native languages (Alvarez \& Rios, 2012; Valenzuela, 1999).

Zero-tolerance discipline policies in schools are also considered to be race neutral; yet stark racial disparities in discipline outcomes continue to be reported (Cahill, Alvarez Gutiérrez, \& Quijada Cerecer, 2016; Fenning \& Rose, 2007; Gregory, Skiba, \& Noguera, 2010). Researchers have found that minoritized students are more likely to be suspended for nonviolent issues, such as class disruption and disrespecting teacher authority, whereas white students are often excused for similar behaviors (Bonilla Silva, 2015; Fenning \& Rose, 2007; Gregory et al., 2010; Peguero, Bondy, \& Shekarkhar, 2017). These systemic racial inequities also reveal epistemic racial biases in K-12 systems when examining school leadership, pedagogical practices, and school-based policies that seek to control and surveil the bodies and minds of students of color (Alvarez Gutiérrez, 2015; Alvarez Gutiérrez \& Quijada Cerecer, 2014). The racialization of knowledge in schools becomes apparent when examining educational disparities that illuminate achievement and opportunity gaps resulting from the racialization of immigrant students in schools. This racialized system is framed by colonial ideologies that perpetuate young people of color being pushed out of school and into the criminal justice system (Gregory et al., 2010; Peguero, Ovink, \& Li, 2015).

Racial and ethnic educational and discipline disparities continue to exist in US public schools. These are a result of the widespread practices that devalue immigrant and minoritized students' knowledge and position them on the periphery of educational success. This marginalization is sustained by prevailing implicit biases and meritocratic ideologies held by educators (Alvarez Gutiérrez, 2015). Gregory, Skiba, and Noguera (2010) refer to the racial and ethnic "academic gap" and the racial and ethnic "discipline gap" as "two sides of the same coin" (p. 59). The racial and ethnic academic gap refers to inequities in K-12; whereas, the discipline gap refers to the school-to-prison pipeline, a byproduct of zero-tolerance policies, which are uncompromising school rules aimed at controlling student behavior. The discipline gap illustrates the significant racial disparities in school suspensions and expulsions. Race-neutral and neoliberal policies and practices sustain systemic racial disparities that hinder the promotion of immigrant students in P-20 educational systems (Cahill, Alvarez Gutiérrez, \& Quijada Cerecer, 2016). As Cahill, Alvarez Gutiérrez, and Quijada Cerecer (2016) state: "The reproduction of neoliberal educational practices and policies that maintain a system of racial stigmatization and racial disparities are destructive for the advancement of immigrant students" (p. 5). In effect, these practices and policies sort and discipline young people of color, and in particular, young immigrant and undocumented students for particular roles in the labor force.

Research further reveals strong links between zero-tolerance policies and academic failure, low test scores, and an increase likelihood of being pushed out of school (Gregory et al., 2010; Peguero, Bondy, \& Shekarkhar, 2017). In other words, by design, so-called race-neutral policies 
are not race neutral (i.e., zero-tolerance policies), and they generate and sustain a social control system (through a disciplinary program) that is racialized and classed in K-12 schools, through the creation of uncompromising punishments. This system (and its disciplinary praxis) also tracks students into low-paying jobs - creating a formal exploitation of labor which results in a secluded low socio-economic class which Cahill, Alvarez Gutiérrez, and Quijada Cerecer (2016) term the "school to sweatshop" pipeline. More specifically, the school to sweat shop pipeline refers to the academic tracking of students in school that funnels them into a low-paying labor market.

Taking our cue from Cahill, Alvarez Gutiérrez, and Quijada Cerecer's (2016) concept of the school to sweatshop pipeline, we explore how engaging immigrant students and families with school can collectively help reframe the academic gap and discipline gap with the use of CPAR projects to empower students and their families' funds of knowledge: "the historically accumulated and culturally developed bodies of knowledge and skills essential for household or individual functioning and well-being" (i.e., customs, cultural and linguistic practices) (Moll, Amanti, Neff, \& Gonzalez, 1992, p. 133), as well as a sense of belonging.

\section{Sense of Belonging}

It is essential that immigrant students feel like they are valued and welcomed into the school context. Due to past traumas, separations at the border, stress and anxieties regarding safety, immigrant students may face challenges in adjusting to their new school contexts, which are often discriminatory (Lustick, 2017; Portes \& Rambaut, 2014). Besides constantly living in fear and uncertainty due to the anti-immigrant climate, some of the challenges faced by immigrant students include: 1) attending schools and/or being placed in classrooms that are Englishdominant, creating communication challenges for emergent bilinguals; 2) unfamiliarity with the educational system, school policies, and daily routines (e.g., expectations, assessment practices) in the United States; and 3) social isolation created by enrolling most emergent bilinguals in the same classes throughout the day, weakening social bonds to the larger student body (Alvarez Gutiérrez, 2015; Cahill, Alvarez Gutiérrez, \& Quijada Cerecer, 2016; Garcia, Kleifgen, \& Falchi; Gonzales, 2016; Passos DeNicolo, Yu, Crowley, \& Gabel, 2017; Peguero, Ovink, \& Li, 2015). Research suggests that students who feel connected to school are more likely to succeed both academically and socially (Alvarez Gutiérrez, 2015; Lowenhaupt, 2014; Passos DeNicolo, et al., 2017; Sarr \& Mosselson, 2010). Therefore, it is essential for educators to legitimize immigrant students' sociocultural and political histories in the curriculum and prioritize their current needs (Sarr \& Mosselson, 2010). Doing so validates young people's identities as immigrant students and as academic learners and sustains their engagement in schools (Alvarez Gutiérrez \& Quijada Cerecer, 2014; Lowenhaupt, 2014; Paris \& Alim, 2017; Turcios-Cotto \& Milan, 2013; Williams, Sánchez, \& Hunnell, 2011).

We assert that "cariño conscientizado" (Passos DeNicolo, Yu, Crowley, \& Gabel, 2017) reimagines and reconceptualizes sense of belonging for immigrant students. Cariño conscientizado draws from Freire's (1970) conceptualization of critical consciousness and critical care scholarship (Valenzuela, 1999; Valdes, 1999) that disrupt the structural racism that sustains epistemic racism and biases that impede immigrants' sense of belonging in K-12 schools (Passos DeNicolo, Yu, Crowley, \& Gabel, 2017). Cariño conscientizado reveals the multiple interlocking and intersecting layers of power and how they impact the learning of immigrant students. When students feel they belong to the larger school culture, they are more successful academically and socially. While Peguero, Ovink, and Li (2015) suggest that "strong social bonds to school have the potential to mitigate some of the observed racial/ethnic gaps in dropout risks" (p. 1), the research does not appear to account for racialized inequities due to structural racism that manifests in curriculum and tracking. Therefore, it is important that educators take direct actions to reject neutrality and 
colorblind approaches in their praxis. Instead, educators need to embrace authentic care, which are "sustained reciprocal relations between teachers and students as the basis of all learning" (Valenzuela, 1999, p. 61). It is then that schools can become sites where educators are able to imagine and create humanizing learning environments where students thrive and collectively imagine and envision a better today and hopeful tomorrow.

Culturally sustaining family-school engagement practices (Paris \& Alim, 2017) become increasingly important as they have been associated with students feeling a sense of belonging and have a variety of positive academic, social, and emotional outcomes, including higher grade point averages (Gutman \& Midgley, 2000) and overall increased academic success (Hoover-Dumpsey, et al., 2005). More specifically, Culturally Sustaining Pedagogy (CSP) attempts to "foster-to sustain - linguistic, literate and cultural pluralism as part of schooling for positive social transformations (Paris \& Alim, 2017, p. 1). CSP emerged from Culturally Relevant Pedagogy (Ladson Billings, 1995), which promotes additive learning and denounces pedagogical practices that subtract students' linguistic and cultural assets. Ladson-Billings (2017) further suggests that culturally sustaining pedagogical practices offer the opportunity for trusting relationships to develop among students, families, and schools.

As such, the research presented in this article emerges from a longitudinal qualitative study focused on a community-based university partnership: Family School Partnership (FSP). In this research, we specifically explore how a group of immigrant students and their families in an English Language Development (ELD) program resist invisibility and create change through a CPAR project. More specifically, this CPAR project focuses on "participatory moves" (Cahill, Alvarez Gutiérrez, \& Quijada Cerecer, 2016) that position immigrant students and their families as transformative agents who produce knowledge, imagine career and life possibilities, inspire hope, and influence change and prospects within educational organizations and communities. In the following sections, we describe the importance of developing strong family engagement practices with immigrant and refugee families. Drawing on the concept of culturally sustaining pedagogy (CSP) (Paris \& Alim, 2014; 2017), we offer a framework for how families, schools, and communities might create more inclusive educational environments (Alvarez Gutiérrez, 2015; Alvarez Gutiérrez \& Quijada Cerecer, 2016; Cahill, Alvarez Gutiérrez, \& Quijada Cerecer, 2016). Next, we share the example of how one university partnership-FSP sought to enact these goals through the use of CPAR focused on the immigration experiences of young people and their families, as well as how these experiences have shaped how they experience education in the United States. Finally, we conclude with a call to action to educators, school leaders, and university faculty, including teacher educators, on how to use CPAR projects to value and integrate immigrant students and families within schools.

\section{Theoretical Framework}

How can schools seek to address systemic racism that is so deeply embedded in schools and organizations? This is a multifaceted problem, but working to create stronger relationships with students and families will certainly be an important part of this process. We argue that educators can practice culturally sustaining pedagogy (CSP) in their schools. CSP incorporates students' lived experiences and knowledge derived from home and community to inform curricular design and how relationships should be formed with students and families (Alvarez Gutiérrez, 2015; Alvarez Gutiérrez \& Quijada Cerecer, 2016; Cahill, Alvarez Gutiérrez, \& Quijada Cerecer, 2016; Paris \& Alim, 2014; 2017; Passos DeNicolo, et al., 2017). Culturally sustaining pedagogy further asserts that educators must recognize that cultures are contextually based and multidimensional. This requires educators to not only be sensitive to students' cultural backgrounds, but to also be culturally competent to integrate, sustain, and extend the lived 
experiences of immigrant students into their curriculum and pedagogical practices. Equally important are pedagogical strategies that foster students' learning while supporting students in developing relationships that help build a sense of belonging. Relatedly, educators must be trained to recognize their own privileges and implicit biases, particularly when decisions about curriculum and policies impact students (Alvarez Gutiérrez, 2013; 2015; Camarota, Griffith, \& Zeigler, 2017; Ferlazzo, 2017; Gonzales, 2016). More specifically, Paris and Alim (2014) eloquently remind us that:

CSP seeks to perpetuate and foster - to sustain - linguistic, and cultural pluralism as part of schooling for positive social transformation. CSP positions dynamic cultural dexterity as a necessary good, and see the outcome of learning as additive rather than subtractive, as remaining whole rather than framed as broken, as critically enriching strengths rather than replacing deficits. Culturally sustaining pedagogies exists wherever education sustains the lifeways of communities who have been and continue to be damaged and erased through schooling (p. 1).

Culturally sustaining pedagogies respond to educational inequities and structural racism that impact the development of immigrant students' academic identities, "as a needed response to demographic and social change" (Paris \& Alim, 2014, p. 88). Curriculum, pedagogy, and relationships emerge that honor and legitimize students' lived experiences when their ethnic and racial histories are centered within these structures. In so doing, educators legitimize the knowledge systems and experiences students bring from their families, homes, and communities and empower students to actively participate and engage in the production of knowledge, or what is viewed as knowledge in classrooms and schools. As such, CSP explicitly calls for K-12 public educators to sustain - rather than subtract or assimilate - the knowledge young people of color bring to schools (Lowenhaupt, 2014). To enact CSP in schools it is imperative that families and schools build stronger, reciprocal relationships so communities feel interconnected and valued by the school. In our work, we have utilized CPAR as a means to legitimize students' knowledge and facilitate closer relationships among students, families and teachers.

\section{Methodology}

Founded in 2008 by Leticia Alvarez Gutiérrez, Family School Partnership (FSP ) is a community-based university partnership with the university licensure program, University Neighborhood Partners (UNP), the Equity Department in the Salt Lake City School District, as well as with school administrators and teachers who serve west-side, English-emergent bilingual students. FSP developed after a year of meetings with the above partners. Conversations centered on identifying and understanding the pressing needs of immigrant and refugee students and families as well as the concerns expressed by educators. After six months of conversations with the school representatives, it became clear that a central concern for school officials was a "lack of immigrant family engagement at the school, their presence at the school, and care for their students' academic progress" (personal communication, November2007).

The principal stated: "We don't know how to get these immigrant and refugee students and their families to care enough about school." One of the other administrators shared that "we need to have some way of telling these groups about how important school is, because they don't seem to care - they don't attend back to school nights or other parent meetings" (personal communication, December, 2007). The ELD educators in this study had a different perspective on the issue. They expressed that "immigrant and refugee students did care about school, but that they didn't feel valued in the school" (researcher notes, December, 2007). After six months of meetings with school administrators and ELD teachers, we agreed that the school should prioritize culturally 
relevant ways to engage immigrant and refugee families at the school. After Leticia spoke with the above partners, she then met on a consistent basis with immigrant students and their families to learn more about their concerns at the school. Immigrant students and their families communicated concerns about feeling isolated, marginalized, and not belonging at the school. Thus, FSP was created as a result of these conversations and became the link of communication between the university's licensure program, school district, teachers, and immigrant students and their families.

FSP strives to create a refugio [safe haven] to engage and address the participants' pressing concerns (e.g., high school graduation, equitable access to college or career opportunities, tracking, racial profiling and school surveillance, and educational policies and practices) (Alvarez Gutiérrez, 2015). In addition, FSP seeks to increase equity in schools while providing students with greater access to resources and higher education. FSP also works to provide a platform for immigrant and refugee students and families to voice their lived experiences and educational goals and is guided by the following two objectives: 1) increase immigrant and refugee family engagement with schools; 2) strengthen a supportive and inviting school culture for immigrant and refugee students and their families, while also providing educational and community resources. Finally, FSP seeks to provide opportunities for teacher licensure students and in-service educators to integrate CPAR projects which involve families and communities.

The co-researchers in the Creative Expressions CPAR project included immigrant high school students, their families, ELD high school teachers, as well as secondary licensure students, graduate students, and the founder and director of FSP. The ELD high shool teachers were two white females who have been teaching for over twenty years. There were approximately 150 ninthtwelfth grade high school students who participated in the Creative Expressions project and were enrolled in the ELD classes. Students identified as either immigrants, children of immigrants, and/or refugee, and many were emergent bilinguals learning English. Many of these students were recent immigrants from a broad range of places including Bosnia, Croatia, Iraq, México, Sarajevo, Somalia, and Vietnam. The two ELD teachers were highly respected among the immigrant and refugee communities for their advocacy and ongoing support to students and families. The teachers were not only educators, but also served as mentors, social workers, and as liasions between families and social services agencies. It was also common for the teachers to visit the students' homes to learn more about their families' experiences in the US. The teachers were passionate about creating safe learning spaces. One of the teachers, who lives in the school community, exemplified this in a statment made after being named 2017 Teacher of the Year by the state. "My teaching is driven by a powerful belief in human dignity and a basic respect between teacher, student, and family." Both of the teachers who helped develop the Creative Expressions CPAR project were constantly finding ways to support immigrant students and their families.

Pre-service teachers were also involved in the project and enrolled in a Family School Partnership university course. Two female graduate students of color working as co-coordinators alongside the FSP director were also involved. The graduate students worked closely with the preservice teachers in the required course and in the high school and community. In addition to the graduate students, FSP also worked with a local artist. The artist guided the creation of a mural that accompanied this project and was part of an artist-in-residence component for Creative Expressions. However, this article only focuses on the writing that occurred through the language arts curriculum.

Critical Participatory Action Research (CPAR) is an approach to research in communities that emphasizes both participation and action and engages individuals in transformational resistance, educational praxis, and critical epistemologies. Through participation in CPAR, individuals can learn to recognize that institutions and social conditions are set up to oppress minoritized communities and enables communities to enact their agency to address and resist these 
oppressive conditions while developing their conscientization. In other words, critical "PAR commits at once to human rights, social justice, and scientific validity" (Torre, Fine, Stoudt, \& Fox, 2012, p.182).

CPAR has four fundamental criteria that inform most projects: (1) collective commitment to investigate an issue or problem; (2) desire to engage in self- and collective reflection to gain clarity about the issue under investigation; (3) [establishes a] joint decision to engage in individual and/or collective action that leads to a useful solution that benefits the people involved; and (4) the building of alliances between researchers and participants in the planning, implementation, and dissemination of the research process (McIntyre, 2008; Tuck \& Fine, 2007). The Creative Expressions project forefronts the immigrant co-researchers' voices. In alignment with the principles of CPAR, Creative Expressions was co-constructed and designed by all members of the research team. Each dimension of the project and emerging issues were discussed, ensuring full transparency from beginning to end (e.g., institutional review board approval, analysis, curriculum, etc.). As such, the CPAR project titled Creative Expressions offered teachers, pre-service teachers, and graduate students unique opportunities to work with and learn from immigrant and refugee students and their families. This project is important for students because the persistent antiimmigrant fervor in the US impacts young people's adjustments in socially and in school.

\section{Salt Lake City and Hopeful High School}

Salt Lake City (SLC), Utah, is located in the Rocky Mountains, with close to 200,000 residents. Approximately $65 \%$ of residents identified as ethnically and linguistically diverse in the 2010 census, making SLC the most diverse in Utah (Downen \& Perlich, 2013). State demographics report that one in seven people identify as Latinx, and $36.2 \%$ of immigrants in the state are naturalized citizens. The Latinx community is the fastest growing population in the state (Camarota, Griffith, \& Zeigler, 2017). The residential areas are segregated by race/ethnicity and income, with the majority of people of color and working-class residents living on the west side of Salt Lake City. In fact, 76\% of west side residents identify as Latinx. SLC's west side is often labeled by the media as being "high crime" and a dangerous area (Downen \& Perlich, 2013). Despite Utah's notorious stance on passing anti-immigrant policies (e.g., HB 497, Show me your Papers Please), it is one of 18 states that has provided in-state tuition for undocumented students (HB 144) since 2001.

One of the schools serving the west side of Salt Lake City is Hopeful High School. At the time of the research, Hopeful High School's student population was close to 2,500, and 63\% $(1,575)$ of the student body identified as minoritized students. The majority of the students of color were Latinx (41\%) and 73\% were labeled "economically disadvantaged" by the Salt Lake City School District (SLCSD). The state of Utah reports $86 \%$ of students graduate from high school, yet in the SLCSD, the graduation rate is $77 \%$. For immigrants who are bilingual-emergent, the graduation rate ranges from $61 \%$ to $72 \%$; whereas, graduation rates in high schools with mostly white middle class students range from $95 \%$ to $98 \%$. There are definite graduation disparities in the state Utah between students of color and white students.

\section{CPAR Procedures and Data Analysis}

During the eight-week Creative Expressions CPAR project, immigrant students and families met with high school teachers, secondary pre-service teachers, graduate students, a local community artist, and community agencies, as well as with the director of FSP. The secondary preservice teachers, along with the graduate students, met with the director of FSP to plan how best to support the students, families, and teachers. The Creative Expressions project commenced by having the research team, including students, establish community agreements. These community 
agreements were co-constructed to create a respectful and trustworthy space. Once agreed upon by all the research team members, students and their families shared their immigration journeys and in-school educational experiences. These conversations commenced with a small icebreaker and then had an informal protocol to help guide the discussion; however, the issues discussed were based on the groups' concerns: school suspension, school absence, racism, anti-immigrant. Most conversations with students took place during school hours and in the ELD classrooms, facilitated by teachers. The dialogue with the larger group, which also included families, occurred after school and on weekends, with a few conversations occurring during school hours.

Holding space through these conversations strengthened relationships and provided an opportunity to develop and generate topics and interview questions related to student experiences with immigration and the school. In addition to their participation in the interviews, students and family members were asked to share a treasured image of their family. Students and family members shared pictures of extended family members, home countries, ranches, and animals. Once interviews were completed, the high school students wrote their own stories for the Creative Expressions project. The high school student stories and interviews with family members were used as data sources for this research. While various themes emerged (e.g., economic instability, difficulties learning English, immigration status, access to higher education) in the students' narratives, for the purposes of this article we focus on their families' experiences regarding: 1) immigration \& family, and 2) education. In these stories, young people expressed the challenges they each experienced during their immigration journey and how these impacted school experiences. These conversations led to critical participatory expressions of writing.

The analysis of the data centered on illuminating how dominant immigration discourses and practices surfaced and impacted the everyday schooling experiences of immigrant students. Data analysis was conducted using an exploratory cyclical process (McIntyre, 2003). During the first spiral, the co-researchers in small groups read and coded students' immigration stories. The data was then reviewed by the first and second authors. Mapping was used to ensure that the thematic analysis was clearly defined (McIntyre, 2003). Co-researchers including students were familiar with mapping techniques since it was a pedagogical tool used in their classes. This collaborative process created a space for the co-researchers and authors to reflect upon, code, and discuss their understandings of the student narratives. Once the students' narratives were coded, co-researchers met in small groups to dialogue and cross check the themes. Co-researchers produced diverse analyses, yet collectively (re)examined, reflected upon, and openly discussed and challenged biases (Fine, 2008). In so doing, "objectivity was neither disregarded nor simply assumed by virtue of distance" (Fine, 2008, p. 223). As a result of this collaborative process, new practices related to awareness of immigrant families were co-constructed by the co-researchers. The findings were presented to the high school community at an evening event that included dinner and research presentations. The event was organized by the two ELD teachers and supported by the research team. For the first time the high school supported a student-centered, multi-lingual event that honored immigrant students and their families. The Creative Expressions event was deemed to be the most successful at the high school, given the students' multilingual research presentations and attended by over 300 people.

\section{Creative Expressions Findings}

The Creative Expressions CPAR project initially began with high school teachers and the lead co-researcher collectively imagining innovative possibilities on how to weave CPAR into the ELD language arts curriculum. Shortly after the initial meeting, small groups of students and family members were invited to join the research team and participate in conversations. A total of fifteen members were part of the research team, which included five high school students, five 
family members, two university students, two ELD teachers, and first author. Meetings consisted of a co-researcher facilitating an innovative activity or series of activities (interactive and/or individualized), designed to spark ideas and creativity. These activities built upon each of the coresearchers existing knowledge and were effective in forming trust and building community within and among the co-researchers. The trust was evident based on the personal experiences and support that the group shared with one another. Each activity explored campus and classroom climates and how these experiences impacted students' identities as learners and young people. For example, co-researchers engaged in a Identity Treasure activity. Co-researchers from each group were asked to decorate the outside of a paper bag with images of how their peers in school perceived them to be and/or how they were readily seen. They were also asked to include five personal items inside the bag that others would not know about them yet wanted to share with the group. Images placed outside the bag were painful to view and experience as these included racial and linguistic stereotypes and images that dehumnized the students and their ethnic and cultural communities (e.g., US Immigration and Customs Enforcement deporting families). Students shared how these images provoked anxiety, fear, and/or triggered past traumas. Items inside the bags included prescription medication such as anti-depression pills; religious symbols such as the Book of Mormon, Bible, or Koran; symbols of gender identity and expressions of sexual orientation; pictures of family members, life at a refugee camp; as well as items that represented negative experiences at the school.

During these meetings, discussions guided by high school students took precedence. For example, it was clear that immigrant students wanted to share their experiences with marginalization and racial stigmatization and did not feel a part of the high school community. Valeria shared, 'I don't feel part of the school. I have been here for three years and don't feel white students know us or really care to know us." Another student in the class named Rafa shared, "I feel like an outsider here. I would like to be involved but it is clear from the looks I get from [white] students that I am not welcome."

When exploring ways to make the school a more welcoming place, students were optimistic in shifting the misconceptions and erroneous beliefs students and educators at the school had of immigrants. Dora, whose family immigrated from El Salvador, believed "students didn't really get why my family and I immigrated to the US. They don't really understand. Maybe if I share my family's immigration story students will begin to understand who we are, know more about me, and stop treating us as outsiders." Manuel, detailed how challenging it was for him to be in school: "people think I can change and just like that forget who I have been for the last 15 years. It just doesn't happen like that; or am I missing something?" Some students believed that by sharing their own educational aspirations and immigration trajectory that other students would learn more about their histories, cultural knowledge and the practices they embody.

Immigrant students and family stories are a source of knowledge (inquiry) for school leaders, educators, and community members as it validates their cultural, linguistic, ethnic heritages and histories, which are seldom legitimized in a curriculum focused on Eurocentric ideologies. Students shared how the curriculum and leadership practices at Hope High School did not reflect their worldviews or lived experiences of immigration or cultural and linguistic backgrounds. For example, Zoey, an active Muslim Southeast Asian student, shared her frustration, "everything is in English in the school, and the lunch is only American food...and Christianity is only acceptable [worldview]... and teachers don't look like us." Using culturally sustaining pedagogy to conceptualize this CPAR project, student co-researchers' lived experiences and emotions were legitimized and integrated into the curriculum. The Creative Expressions book was an outcome of the research project that students created to validate and document their immigration journeys and educational experiences. It is through these culturally sustaining 
practices and creative projects that students finally felt legitimized as active producers of knowledge and engaged learners.

\section{Family Immigration Experiences}

The co-researchers were mindful of how the current national anti-immigrant discourse permeates educational systems and impacts their academic and social experiences at Hope High School. Student co-researchers revealed in conversations and through their writing how political discourse dehumanizes immigrants and positions the immigrant community as criminals seeking to profit from the United States. Journal entries and essays detail the emotional, physical, and spiritual pain students experienced being far from families, friends, and the land that is familiar and a part of them. Erica, shared, "there is a myth that we are all rushing to the United States, but it is much more complicated and is not an easy process." Student co-researchers deconstruct the illusion that has been socially constructed around immigration, particularly immigrants who are minoritized. Maryan, from Kenya, shared that for her leaving her home country was "the saddest thing. It is hard to leave a place that you know about and you were born there." Later Maryan shared how leaving Kenya was painful and extremely hard since her mother had passed away.

Yurbi, born in Kenya and raised in Somalia, shared, "I miss my grandma and my cousins...my grandma used to tell me a lot of stories about our family. I learned so much through these stories and now I miss them." Cynthia, from México, shared that "the hardest thing to do as a family is when we left our country. I try not to cry and just let it go. I don't want to be this depressed person with a heart so broken that it hurts every time I breathe." Cynthia and many students shared how this was the first time in the school that teachers had created safe spaces for them to openly share their immigration journey and how they experienced it. Early on in the class Cynthia revealed how she has learned to cope with her immigration experiences and journey,

I try to forget everything. Think of something else like if it never happened, just smile and hide the pain. But I can't, it's killing me inside to know there are things that happened in my life that could have broken me, but no, it made me who I am now.

For Cynthia, initially trying to "forget everything" and "smiling to hide the pain" reveals the nuanced ways assimilationist ideologies are deeply embedded in the infrastructure of public schools in the United States and how they impact students. These assimilationist ideologies frame institutional practices and permeate school curriculum, policies, and leadership practices. These assimilationist ideologies and are violent acts that seek to discard students' cultural and historical knowledge and practices, and socializes students into embracing a universal knowledge (Quijada Cerecer, 2013). Yet, Cynthia resisted these violent acts that were seeking to assimilate her by making her suppress her cultural and linguistic experiences and identity[ies]. She resisted by recognizing that her lived experiences in México are an important part of her journey and integral to her identity. In so doing, Cynthia enacted her agency and realized that "it [her immigration journey] made me who I am now."

Maryan, Yurbi, and Cynthia share how they experienced loss and pain when immigrating to the United States. The relationships to family, community, and land are central to understanding students' identities and the knowledge embedded in their family and cultural practices. It is through culturally sustaining pedagogy, exemplified by CPAR projects like Creative Expressions, that educators honor students' sociocultural histories, family, and cultural practices, and their lived experiences as immigrant students and young people. Through these projects, immigrant students are legitimized as active change agents engaged in the production of knowledge. 


\section{Educational Visions}

Student co-researchers further revealed how their identities were brought into question and ultimately impacted when examining their ethnicity, immigration status, and education. Central to these co-researchers is the concept of educación. Educación provides a cultural framework for how one should live their life (Valenzuela, 1999) and emphasizes "respect, responsibility and sociality, it provides a benchmark against which all humans are to be judged, formally educated or not" (Valenzuela, 1999, p. 21). For this group of immigrant students, educación was foundational to their identities as young people. Josue from Guatemala shared that for him:

success is not the triumph over regress, success is power to suppress. Success is not the money or fame, success knows you are still the same. My father always tells me, to remember who I am and where I came from because it all reflects on the family because educación is more than book knowledge, it is respect and I am proud of my educación, I got it from my family.

It is values, such as educación, that sustain immigrant students' cultural and linguistic identities, which are integral parts of their identities as students, immigrants, and young people. A parent from México shared the following during one of our afterschool meetings: "Educación es más que lo que un libro puede enseñar - es cultural y es un insulto cuando alguien dice que eres mal educado" [Education is more than a book can teach you, it is cultural, and an insult when someone says 'You are not well educated.'] For this parent, and many others who participated in the FSP project, embodying the values inherent in educacion is essential and core to their identities. To have educacion is to have respect for another individual, a value that is embodied and expressed through individual acts.

Students eloquently illuminate the multiple and complex meanings of educación. For these youth having an educación was foundational to their character and revealed the ways in which one treats another person with dignity and respect. This is a value that was central in how relationships were formed in and out of schools. For example, Lin, a student from Vietnam, stated:

I make friends from different places, and it is because of the way they treat me that I make friends with them. I made a Mexican friend the other day, and we barely understand each other, but we are nice to one another, and I have taught her the routine in Ms. G's classroom.

Joann from Kenya says, "It is difficult to experience racism, because there is more than just the race or religion or language that a person is. It is how a person treats others and how they behave in their family's honor that really matters." JC, a student from Somalia, shared:

In the camp we lived in, everyone was the same, unhappy. It is sad to see how we are treated here because of how we look, because we are much more than how we look. We are good people and try to treat everyone with respect, but I guess not everyone learns that.

There were many multi-ethnic and multi-lingual friendships among students in the Creative Expressions project. Many of the students said, "We're all treated badly because we are black and brown students in a school that doesn't understand us."

Educación for these immigrant students also represents educational attainment as a collective or familial accomplishment. That is, being successful academically was perceived not as an individual goal or as an individual process, but rather as a goal attained collectively through the 
support of the entire family. Muhammad shared, his "dream for the future is to help the people who are blind and handicapped.... I need to get an education, so I can help my country." Josafat from México shared that his family wants him to be a better person, "get a good education and not work as hard as they have.... I will do this because I want a good life and I owe it to my parents for all their sacrifices." Young immigrants feel a responsibility to their families and the sacrifices of constantly working in arduous labor jobs. For example, Maria from México says the following about her dad:

Sometimes after work (construction) he doesn't eat because he just wants to go to bed and get ready for the next day... he works really hard for all of us... sometimes I want to cry and have a lot of money to protect my family...that's why I study really hard because I know my education and job is not only for me but for my family.

Likewise, Claudia shares her drive to graduate from high school and earn a degree. She says she would like to "be a lawyer or a doctor to be able to help my mom with money." The coresearcher's stories in their journals and written work honored their parents and extended family members for negotiating multiple jobs and working long hours to provide food and housing for them and their siblings. For these young students, education was the pathway to a career that might bring financial stability to them and to their family.

Other students shared the challenges of living in the United States while parents and extended family resided in their home countries. Yvonne's parents were deported to México three years ago. Since then she has resided with her aunt and cousins. Yvonne shared how painful and difficult it is for her to be separated from her parents and family members, yet appreciates how they continue to offer support to her. Yvonne shares, "I will do my best to show my parents that their sacrifices were worth it. My goal is to go to college and study medicine. If I work hard, I think my dreams will come true." Quetzali from México aspires to be a nurse so she can support her family. Yet Quetzali shares:

Some days are more challenging than others. These are the days my parents encourage me [to study] in the US in order to have a better life. They don't want me to break my back like they do, working two jobs. My goal is to be a nurse to help support my family, so that my parents don't have to work for very little money.

The student co-researchers share post-secondary aspirations and imagine how attaining an education will position them in career pathways and occupations that will bring financial stability to them and to their families. Yet these students are also cognizant how schools marginalize them through the curriculum and policies. These young people continually strive to engage in transformational resistance by making their identities and immigrant journeys visible, by disrupting deficit notions of immigrants, and by persisting with their education. Despite this, some educators continue to have deficit notions about immigrant students and their families.

Responses from teachers in the high school were surprisingly deficit in nature. A high school female teacher approached Leticia, the FSP director, after the Creative Expressions research presentations and shared: "Wow, I am so impressed with these students. I never imagined them to be researchers or thought they would be capable of writing such profound experiences. I guess I was wrong." One of the white male administrators seemed bothered by the findings and said: "This is the first I hear about these students not feeling welcomed in the school; we haven't had any reports of racism from these students." Another administrator said: 
"I am delighted to see so many students sharing their stories because they are important for us to know... and tell me, how did you get their families to attend? They never attend school functions! Look at the room, it is standing room!"

Another teacher said: "I am glad to see these students and their families in our school. I really have to pay closer attention to some of these students in my class." Pre-service teachers shared how they were surprised to learn from young people and their families, yet gained a true sense of "who immigrants are and their vast contributions."

The responses from administrators and teachers speak to the deficit perspectives that dominate school climate. Responses to the students' presentations are exactly what the CPAR project, Creative Expressions, is attempting to disrupt. Educators need to be exposed to different ideological ways to critically examine their professional responsibilities, their implicit biases and privileges, and how these align to meet the needs of students, or not. A critical educational perspective can be a tool that explores questions such as: What does it mean to achieve? How do my pedagogical practices legitimize the lives of immigrant students? How do I accommodate emergent bilinguals in my classes? How does social justice align with my pedagogy? Why do I do what do? What are the best practices to connect with immigrant students and their families? Culturally sustaining pedagogies can help educators think more deeply about these and similar questions and practices.

\section{Conclusion and Call to Action}

For students participating in the Creative Expressions project, there was a sense of safety and trust for them to express the various ways they have experienced immigration and how they feel marginalized in school. Through the writing and verbal exercises, student co-researchers were able to name numerous ways they experienced marginalization in school and in the classroom as immigrant students. The co-authors and teachers, along with university students, were able to facilitate activities that allowed immigrant students to identify ways to resist and shift how other students perceived them in the classroom. Through this CPAR project, pre-service students and educators acquired an understanding of how culturally sustaining pedagogy builds and strengthens classroom dialogue and fosters classroom community for immigrant students. Equally important, the CPAR project created an opportunity for immigrant students and ELD teachers to share the findings of their research with the entire school community.

ELD teachers were proud that their students were provided with a platform to share their immigration journey and educational aspirations. The findings revealed from this CPAR project were shared at an event that included a sit-down dinner at the school. In attendance were administrators, district assistant superintendents, high school teachers, university students, and of course, the immigrant students and their families. The students' stories were projected on a large screen while the students proudly shared stories, some using a microphone and others walking over and standing alongside their family. The students who read that evening stood proud and confident alongside their family members whose faces lit up with pride. The presentations revealed to administrators and educators the numerous challenges and face and have overcome.

Days after the amazing evening of student research presentations, the teachers and director of FSP met with the school administrators to request that a Family Resource Center (FRC) be made available to students and families. Eight months after the event and several conversations later, the ELD teachers, immigrant students and their families, along with university students, celebrated the opening of a new FRC. The new FRC is a space for immigrant families, students, and educators to meet and learn with and from each other about school and community resources. For example, students and parents are able to learn how to use technology to access student records 
and classes on the computer. Families also organized food and clothing drives to support each other during challenging financial times. In essence, the FRC transpired as a result of the collective work of the ELD teachers, immigrant students and families, pre-service teachers, and graduate students through the Creative Expressions project sponsored by the FSP. Overall, we learned that the Creative Expressions project allowed for closer communication between immigrant students and their families, and the communication between immigrants and teachers improved. This CPAR project allowed for the immigrant students and families to be visible in and out of school.

As we move forward, we call upon school leaders, high school teachers, teacher educators, and university faculty and researchers to engage in work that legitimizes the voices of marginalized and silenced communities and to be change agents in educational institutions and classrooms. We specifically urge school leaders, teacher educators, and university faculty and researchers to work with pre-service teacher candidates to develop cultural competencies and learn how to incorporate CPAR projects in the school curriculum. We also urge community members and social justice allies to demand that schools take seriously their responsibilities to serve all students by accommodating the needs of students and families. We ask that educators take personal agency to dismantle deficit thinking and marginalized practices and stand up to cultural racist praxis in schools.

Equally important is that educators be mindful of how their pedagogical and leadership practices honor and/or silence immigrant students' histories and lived experiences. We also ask that educators critically reflect and determine what and whose knowledge is being valued, privileged, and why? In so doing, we also call upon all educators to critically reflect upon and assess how immigrant student identities are affirmed and visible in school, curriculum, policies, and practices. Immigrant youth have the potential to be influential change agents; however, antiimmigrant discourses and seemingly race-neutral policies preclude educators from positioning immigrant students as actively engaged in the production of knowledge or leaders in creating thriving learning spaces. We conclude by making our final call to all educators to seek and support professional development opportunities that refine our understandings of how Culturally Sustaining Pedagogy and Critical Participatory Action Research projects can enhance the learning for all immigrant students.

Author Note: Leticia Alvarez Gutiérrez, Department of Education, Culture and Society, University of Utah.

This research was supported in part by a university grant as well as support from the Salt Lake City School District, Equity Department.

Correspondence concerning this article should be addressed to Leticia Alvarez Gutiérrez, Department of Education, Culture and Society, SAEC \#3283, University of Utah, Salt Lake City, Utah, 84112. Contact:leticia.alvarez@utah.edu 


\section{References}

Alvarez, L., \& Rios, F. (2012). La politica vecindaria: A macro to micro lens on immigrant newcomer students in US schools. In S. Hughes and T. Berry (Eds.), The evolving significance of race: Living, learning, and teaching (pp. 199-213). New Jersey: Hampton Press.

Alvarez Gutiérrez, L. (2013). Costo alto de politica anti-inmigrante sobre la familia y educación: The adverse consequences of anti-Latino immigration laws. Theory Into Practice, 52, 169-179. doi:10.1080/00405841.2013.804308

Alvarez Gutiérrez, L. (2015). Poder en las voces comunitarias: Immigrant young people and their families' resistance to liminal citizenship in education. Association of Mexican American Educators, 9(2), 31- 44.

Alvarez Gutiérrez, L., \& Quijada Cerecer, P. D. (2014). Teachers' dialogue and transformation: Possibilities of a learner centered professional development initiative in a US urban high school. Pedagogía Social Revista Interuniversitaria, 24, 199-224.

doi:10.7179/PSRI_2014.24.09

Alvarez Gutiérrez, L. \& Quijada Cerecer, P. D. (2016). Undocumented youth, agency, and power: The tension between policy and praxis. In S. L. Nichols (Ed.), Educational policies and youth in the $21^{\text {st }}$ century: Problems, potential, and progress (pp. 39-56). Charlotte, NC: Information Age Publishing.

American Psychological Association (n.d.). Immigration policy: A psychological perspective. Retrieved from https:/www.apa.org/advocacy/immigration/fact-sheet.pdf

Bonilla Silva, E. (2015). The structure of racism in colorblind, "Post Racial" America. American Behaviorist, 59, 1358-1376. doi: 10.1177/0002764215586826

Cahill, C., Alvarez Gutiérrez, L. \& Quijada Cerecer, D. A. (2016). Dialectic of dreams \& dispossession: The school to sweatshop pipeline. Cultural Geographies, 23, 1-17. doi:10.1177/1474474015597431

Camarota, S. A., Griffith, B. \& Zeigler, K. (2017). Mapping the impact of immigration on public schools. Retrieved from https://cis.org/Report/Mapping-Impact-Immigration-Public-Schools

Downen, J. C., \& Perlich, P. S. (2013). Salt Lake City Census 2010 Atlas. Salt Lake City, Utah: Bureau of Economic and Business Research, David Eccles School of Business and The DGIT Lab, Department of Geography at the University of Utah.

Fine, M. (2008). An Epilogue, of Sorts. In M. Fine \& J. Cammarota (Eds.), Revolutionizing Education: Youth participatory action research in motion. New York: Routledge.

Fenning, P., \& Rose, J. (2007). Overrepresentation of African American students in exclusionary discipline: The role of school policy. Urban Education, 42, 536-559.

Garcia,O., Kleifgen, J. A. \& Falchi, L. (2008). From English Language Learners to emergent bilinguals. Research Review 1, 5-59. Retrived from https://files.eric.ed.gov/fulltext/ED524002.pdf

Geiger, A. (2018). America's public school teachers are far less racially and ethnically diverse than their students. Retrieved from http://www.pewresearch.org/facttank/2018/08/27/americas-public-school-teachers-are-far-less-racially-and-ethnically-diversethan-their-students/ 
Gonzales, R.G. (2016). Living lives in limbo: Undocumented and coming of age in America. Oakland, CA: University of California Press.

Gregory, A., Skiba, R. J., \& Noguera, P.A. (2010). The achievement gap and the discipline gap: Two sides of the same coin? Educational Researcher, 39, 59-68.

Gutman, L. M., \& Midgley, C. (2000). The role of protective factors in supporting the academic achievement of poor African American students during the middle school transition. Journal of Youth and Adolescence, 29, 223-249.

Hoover-Dempsey, K., Walker, J., Sandler, H., Whetsel, D., Green, C., Wilkins, A., \& Closson, K. (2005). Why do parents become involved? Research findings and implications. The Elementary School Journal, 106, 105-130. doi:10.1086/499194

Ladson-Billings, G. (1995). But that's just good teaching! The case for Culturally Relevant Pedagogy. Theory into Practice, 34(3), 159-165.

Ladson-Billings, G. (2017). The (R)Evolution will not be standardized: Teacher education, hip hop pedagogy, and Culturally Relevant Pedagogy 2.0. In D. Paris \& H. S. Alim (Eds.), Culturally Sustaining Pedagogies: Teaching and learning for justice in a changing world (pp. 141-156). New York, NY: Teachers College Press

Lee, T. S., \& Quijada Cerecer, P. D. (2010). (Re) Claiming Native youth knowledge: Engaging in socio-culturally responsive teaching and relationships. Multicultural Perspectives, 12, 199-205. doi:10.1080/15210960.2010.527586

Lowenhaupt, R. (2014). School access and participation: Family engagement practices in the new Latino diaspora. Education and Urban Society, 46, 522-547.

Lustick, H. (2017). Making discipline relevant: toward a theory of culturally responsive positive schoolwide discipline. Race Ethnicity and Education, 20, 681-695. doi:10.1080/13613324.2016.1150828

McIntyre, A. (2008). Participatory action research: Qualitative research methods (Series 52). Thousand Oaks, CA: SAGE.

Menjívar, C. (2006). Liminal legality: Salvadoran and Guatemalan immigrants' lives in the United States. American Journal of Sociology, 111(4), 999-1037.

Moll, L. C., Amanti, C., Neff, D., \& González, N. (1992). Funds of knowledge for teaching: Using a qualitative approach to connect homes and classrooms. Theory into Practice, 31, 132-141.

Morris, M. W. (2016). Pushout: The criminalization of Black girls in schools. New York, NY: The New Press.

National Center for Education Statistics. (2018). State nonfiscal survey of public elementary and secondary education, 1998-99 through 2015-16; and national elementary and secondary enrollment by race/ethnicity projection model, 1972 through 2027. Retrieved from https://nces.ed.gov/pubs2018/2018138.pdf

Paris, D., \& Alim, H.S. (2014). What are we seeking to sustain through Culturally Sustaining Pedagogy? A loving critique forward. Harvard Educational Review, 84, 85-100.

Paris, D., \& Alim, H. S. (Eds.). (2017). Culturally Sustaining Pedagogies: Teaching and learning for justice in a changing world. New York City, NY: Teachers College Press. 
Passos DeNicolo, C., Yu, M., Crowley, C. B. \& Gabel, S. L. (2017). Reimagining critical care and problematizing sense of school belonging as a response to inequality for immigrants and children of immigrants. Review of Research in Education, 41, 500-530.

Peguero, A. A., Bondy, J., \& Shekarkhar, Z. (2017). Punishing Latina/o youth: School justice, fairness order, dropping out, and gender disparities. Hispanic Journal of Behavioral Sciences, $39,98-125$.

Peguero, A. A., Ovink, S. M., \& Li, Y. S. (2016). Social bonding to school and educational Inequality: Race, ethnicity, dropping out and the significance of place. Sociological Perspectives, 59, 317-344. doi:10.1177/0731121415586479

Portes, A., \& Rumbaut, R.G. (2014). Immigrant America: A portrait. (4th ed.) Berkeley, CA: University of California Press.

Quijada Cerecer, P. D. (2013). The policing of Native bodies and minds: Perspectives on schooling from American Indian youth. American Journal of Education, 119, 591-616. doi.org/10.1086/670967

Sarr, C. U., \& Mosselson, J. (2010). Issues in teaching refugees in US schools. Yearbook of the National Society for the Study of Education, 109, 548-570.

Torre, M. E., Fine, M., Stoudt, B. G., \& Fox, M. (2012). Critical participatory action research as public science. APA Handbook of Research Methods in Psychology, 2, 171-184.

Tuck, E., \& Fine, M. (2007). Inner angles: A range of ethical responses to/with Indigenous and decolonizing theories. In N. Denzin \& M. Giordino (Eds.), Ethical futures in qualitative research: Decolonizing the politics of knowledge (pp. 145-168). Walnut Creek, CA: Left Coast Press.

Turcios-Cotto, V. Y. \& Milan, S. (2013). Racial/ethnic differences in the educational expectations of adolescents: Does pursuing higher education mean something different to Latino students compared to White and Black students? Journal Youth and Adolescence, 42, 1399-1412. doi:10.1007/s10964-012-9845-9

US Census Bureau (2015). Projections of the size and composition of the US population: 2014 to 2060: Population estimates and projections. Retrieved from https:/www.census.gov/content/dam/Census/library/publications/2015/demo/p25-1143.pdf

Williams, T. T., Sánchez, B. \& Hunnell, J. (2011). Aligning theory with practice: Understanding school-family partnerships at an inner-city high school. Children and Youth Services Review, 33, 689-697.

\section{Note}

${ }^{1}$ Name of school and student names are pseudonym 